\title{
The Case for Nation Branding as an Investment Promotion Methodology for African Nations: A Literature-Based Perspective
}

\author{
Tafadzwa Matiza \\ Department of Business Management, University of Limpopo, \\ Turfloop Campus, South Africa \\ Email:matizata@hotmail.com \\ O.A Oni \\ Department of Business Management, University of Limpopo, \\ Turfloop Campus, South Africa \\ Email: olabanji.oni@ul.ac.za
}

Doi:10.5901/mjss.2014.v5n3p262

\begin{abstract}
This paper discusses the contribution of nation branding theory and practice to the promotion of foreign direct investment. This discussion is in particular reference to Africa as an investment location and the image challenges that individual African nations face as a result of being associated with the African brand. The paper is qualitative in nature and is based on secondary data. As a result of this review of literature, it emerged that Africa suffers from a negative image challenge and that the stereotypes that exist of Africa as a continent have a negative causal effect on FDI inflows into African economies. Significantly, this paper posits that nation branding can make a significant contribution in the image-building aspect of the investment promotion process. This paper concludes that African nations need to manage the perceptions of foreign investors by proactively managing their images before embarking on investment generation activities. This entails the establishment and management of the nation brand images of individual countries as investment destinations as the initial step in traditional investment promotion practice. However, more importantly this paper advocates for empirical research to establish a theoretical framework that links nation branding theory with image-building practice in investment promotion.
\end{abstract}

Keywords: Africa, foreign direct investment, investment promotion, nation branding, nation images

\section{Introduction}

Africa faces a myriad of developmental challenges, and the continent's inability to attract foreign direct investment (FDI) is according to Sichei and Kinyondo (2012) 'troubling' given the potential of FDI as a solution the continents' socioeconomic challenges. Although Africa as an investment destination has investment locations that offer investors some of the world's highest rates of return on investment (World Bank, 2010 cited in Darley, 2012), the continent as a whole attracts only up to $5.3 \%$ of the total global FDI flows (Sichiei \& Kinyondo, 2012). According to the United Nations Industrial Development Organisation (UNIDO, 2011), Sub-Saharan Africa accounts for only between $1 \%$ and $2 \%$ of total global FDI flows. These low figures are an indication of an underlying negative image and generally negative perception challenge being faced by African nations as investment destinations. The image of a nation/country is in essence the picture, reputation or stereotype that is attached to a specific country, (Grundey, Tolub \& Brukiene, 2006) and nation images, much like those of corporate and product brands are susceptible to negative perceptions and stereotypes. In the case of African nations, the mere mention of the continent evokes images of war, civil unrest, deadly diseases, poverty, starvation and economic disorder, (Moyo, 2010, Mwilima, 2003, Annan, 1999 cited in Odenthal \& Zimny, 1999). As a result, Africa as a whole is perceived generally as an unfavourable location for foreign investment (Mwilima, 2003), with most investors 'discounting' the continent as an investment destination altogether, (Odenthal \& Zimny, 1999).

The negative image that Africa has as a region has burdened most of its 53 individual and distinct economies with the negative association of being located on the 'Dark Continent'. This assertion is supported by the United Nations (UN, 1995) which identified the region's negative image as the major obstacle in investment promotion for African nations. More recently, Moyo (2010) echoed a similar view, pointing out that Africa as a continent has a 'bad brand' which actually encourages the reduction in FDI to the continent. To this end, Blancheton and Opimba (2010) determine that African 
nations need to manage and contain the 'risks' that 'curb the enthusiasm' of investors and harm the external image of the continent as a whole in order to attract much needed FDI. Unfortunately in the case of Africa, the atrocious aspects of the continent receive the most media attention at the expense of more positive developments which are seldom reported on and not widely known (Mwilima, 2003). The stereotypes attached to most African nations such as those of war [Angola], famine [Somalia \& Ethiopia], poverty [Malawi], corruption [Nigeria] and economic disorder [Zimbabwe], inform the investment decisions of foreign investors. Even if these factors are no-longer relevant to the particular country, Dinnie (2008) warns that they still impinge on the ability of the associated nations to attract economic activities such as FDI, and conceal the complex diversity of economic performance and the existence of investment opportunities in individual African countries, (Odenthal \& Zimny, 1999).

The active management and projection of a nation's identity is referred to as the practice of nation branding. According to BrandFinance (2013), developing the nation brand allows a country to attract greater FDI by increasing the interest of investors in opportunities within a nation. To provide a platform for the discussion of nation branding as a potential strategy in FDI promotion, this paper focuses on the definitions and key themes surrounding the concept of nation branding, as well as the commercial relevance of nation branding. These aspects are highlighted before an examination of the global role of nation branding, and primarily for the purposes of this paper, the contribution of nation branding as a tool for FDI promotion for nations, as well as the potential benefits to governments, of employing nation branding as an investment promotion tool. Therefore, this paper primarily, but not exclusively, seeks to inform on the following questions;

i. What is nation branding, and is it a relevant commercial concept?

ii. Does nation branding make any contribution in the facilitation of foreign direct investment promotion?

iii. Is nation branding a feasible strategic nation image-building approach to foreign direct investment promotion for African nations?

\section{Nation Branding: Definition and Themes}

The past decade has seen branding evolve to become a key element in marketing management, and more recently rise in prominence and application in other fields viz. politics; international trade; business and; sport. Branding, which primarily focuses on achieving product/service differentiation, and value exchange in the marketing process, has however, "come a long way since its early purpose of signifying livestock ownership, military insignia, natural identification, and religious affiliation," (Venter \& van Rensburg, 2009:211), to become a strategic marketing tool, in a global market characterized by increased standardization and competition.

Nation branding is not altogether a new concept in practice, it is, however, relatively 'new' in theory, when compared to other traditional concepts in marketing, such as corporate and product branding. Nations have on the other hand been practicing branding in diverse disciplines for decades, in the form of political marketing (public diplomacy) and tourism marketing (place/destination branding), Fan (2009). Dinnie (2012) similarly suggests that it can be argued, that there is nothing all too new about nation branding, as nations through their flags, currencies and anthems, have historically branded themselves. However, as Dinnie (2012) points out, what is new is the application of commercial marketing and branding concepts to whole countries. For one to get a holistic impression of the meaning of nation branding, it is prudent to define what is meant by the term brand, and more importantly what a nation brand is, before defining nation branding.

\subsection{Defining the Nation Brand}

Nyman and Rehn (2008) argue that brands are not exclusively represented through products and services, but that individuals and places may also be brands. With this in mind, Fan (2006:19) seems to simply augment the classic AMA (1960) definition of a brand, to define a nation brand as, "The design, symbol, sign, colour, or any combination of these that are used to deliver a symbolic meaning to the nation's stakeholders." While, Dinnie (2008) posits a richer definition of a nation brand, describing a nation brand as, "The unique multi-dimensional blend of elements, that provides the nation with culturally grounded differentiation and relevance, for all its target audiences."

That is not to say that the definition put forward by Fan (2006) is inadequate, but for the purposes of this paper Dinnie's (2008) description of the nation brand encompasses the fundamental aspect of the nation brand, as being multidimensional, and being based on differentiation, that is relevant to particular stakeholders. To this end, Skinner and Kubacki (2007) cited in de Best (2010), bluntly describe nation branding as simply a process that establishes a nation 
brand, however, defining nation branding is not as candid as that.

\subsection{Defining Nation Branding}

Describing the commercial branding process, Blythe (2009), rationalizes the process to be the development of specific identities for products, by focusing on the creation of perceptions, which would ultimately distinguish one product from the other. Knapp (2008) on the other hand is cited in Venter and van Rensburg (2009) for the narrative of branding as being, the internalized sum of all impressions received by customers and consumers, in a distinctive position in their 'mind's eye' based on perceived emotional and functional benefits. It is these perceived emotional and functional benefits that nations seek to exploit within their target audiences and garner competitive advantage, through positioning, in an attempt to create positive perceptions of the nation. Such positive perceptions would 'perhaps' not be forthcoming, if a nation does not actively manage its identity, and leave its reputation at the decrement of the media, competitors and existing stereotypes and clichés, (Dinnie, 2008).

The image of nations as brands is a central concept in several research fields namely Country of Origin (COO), Public Diplomacy, and Destination/Place Branding, with the resultant proposition being, that the image of a country has a marked effect on the actions and activities of individuals, that is, global political leaders, investors and consumers, (Avraham \& Ketter, 2008). However, from a marketing management perspective, Helmi and Mulyanegara (2011) suggest that there are four key theoretical foundations underpinning nation branding (Table 1);

Table 1: Theoretical Foundations of Nation Branding

\begin{tabular}{|l|l|}
\hline \multicolumn{1}{|c|}{ Field of Study } & \multicolumn{1}{c|}{ References } \\
\hline Country of Origin & Parameswaran \& Pisharodi, 1992; Roth and Romeo, 1992; Shimp, Saeed, and Madden, 1993. \\
\hline Country-product Image & Martin and Eroglu, 1993; Parameswaran and Yaprak, 1987. \\
\hline Destination Branding & Hankinson, 2007; Pritchard and Morgan, 1998. \\
\hline Country Identity & Anholt, 2007; Keillor and Hult, 1999; Keillor, Hult, Erffmeyer, and Babakus, 1996 \\
\hline
\end{tabular}

Source information: Helmi and Mulyanegara (2011:36)

While admitting that nation branding is exciting, given its theoretical infancy and wide real-world practice, Dinnie (2008) conversely acknowledges that nation branding is both complex and controversial, as it encompasses multiple disciplines outside the confines of conventional brand strategy. As such, like any other contemporary business concept, nation branding is subject to a myriad of contextual and practical definitions (Table 2). Notable definitions include those by, Gudjonsson (2005) who pioneers a functional definition of nation branding, as when governments and/or private companies use their power to persuade individuals who have the ability to change their nation's image to positively target influencers.

Fan (2006) digresses from this view, and posits nation branding from a purely commercial perspective, asserting that nation branding is a process that helps a nation 'sell' its products and places, by linking itself to a particular offering(s) to a particular audience(s). Both views [Gudjonsson, 2005 and Fan, 2006] rationalize the key aspects of this paper, by identifying the actors in nation branding, and the concept's primary aim, which in real terms is to positively influence the perceptions of target audiences, towards a nation, and the main commercial objective of nation branding, selling its products and places to target audiences. Table 2 highlights key definitions of nation branding that are relevant to this paper:

Table 2: Key definitions of nation branding relevant to this paper:

\begin{tabular}{|l|c|}
\hline \multicolumn{1}{|c|}{ Definition } & Reference \\
\hline $\begin{array}{l}\text { Using strategic marketing to promote a country's image, products, and attractiveness for tourism and foreign } \\
\text { direct investment }\end{array}$ & (Vicente, 2004) \\
\hline $\begin{array}{l}\text { Nation branding concerns applying branding and marketing communications techniques to promote a nation's } \\
\text { image. }\end{array}$ & (Fan, 2006) \\
\hline $\begin{array}{l}\text { The practice of constructing and communicating a unique image about a specific nation to the rest of the } \\
\text { world through public diplomacy, trade, exports promotion and tourism. }\end{array}$ & (Anholt, 2007) \\
\hline Nation Branding simply refers to the application of corporate branding strategies to individual nations with the & (Teslik, 2007) \\
\hline
\end{tabular}




\begin{tabular}{|l|c|}
\hline aim of influencing foreign affairs and international interactions. & (Szondi, 2008) \\
\hline $\begin{array}{l}\text { The strategic self-representation of a country with the aim of creating reputational capital through economic, } \\
\text { political and social interest promotion at home and abroad. }\end{array}$ & (Fan, 2009) \\
\hline $\begin{array}{l}\text { Nation branding is a process by which a nation's images can be created, monitored, evaluated and proactively } \\
\text { managed in order to improve or enhance the country's reputation among a target international audience. }\end{array}$ & (Marat, 2009) \\
\hline $\begin{array}{l}\text { A process of creating an international reputation about a state and its people. } \\
\text { The adoption of real life policies and tactics following a strategic plan to gain relevance and perceived value in } \\
\text { one or several aspects of a country's reputation. }\end{array}$ & $\begin{array}{c}\text { (Markiessinis, } \\
\text { 2010) }\end{array}$ \\
\hline
\end{tabular}

\section{Source: Author's own construction}

Key ideas in defining nation branding that can be derived from those highlighted in (Table 2) are, that nation branding is premised on the practical application of marketing and branding tactics, aimed at creating a value position for a nation and positively influencing perceptions relevant to the nation's target audiences. Nation branding also aids nations in international relations, and international business competitiveness, by offering a proactive approach to managing a country's reputation and image, both internally and externally. Therefore based on the above definitions, for the purposes of this paper, the researcher employed the following as the working definition of nation branding:

The application of strategic marketing tools and marketing communication techniques, to improve or enhance a nation's image and reputation respectively, among a target international audience, in a bid to enhance public diplomacy, increase trade, promote exports and tourism and ultimately boost inward Foreign Direct Investment (FDI).

The paper's working definition seeks to encapsulate the concept of nation branding, with particular reference to African nation's current challenges with FDI attraction. Nation branding has far-reaching benefits for both developed and more importantly developing nations, whose images and reputations in the global marketplace have, for the most part, adversely affected their overall competitiveness in exports, tourism and more significantly, investment attraction, which is the crux of this paper.

\subsection{Themes in Nation Branding}

Intrinsically tied in with the definition of nation branding, are the thematic perspectives (Table 3) of nation branding, which contextualise the concept within the scope of investment promotion. These themes are important in highlighting the view of nation branding this paper adopts, especially given the fact that nation branding is a multi-discipline concept, and that nation branding strategies and approaches are highly county specific. This means it is important to establish the concept with particular relevance to African nations.

Table 3: Key Nation-branding Themes

\begin{tabular}{|l|c|}
\hline \multicolumn{1}{|c|}{ Theme } & \multicolumn{1}{|c|}{\begin{tabular}{c} 
Author \\
\hline $\begin{array}{l}\text { Nation branding uses the tools of branding to alter or change the behavior, attitudes, identity or } \\
\text { image of a nation in a positive way. }\end{array}$
\end{tabular}} \\
\hline $\begin{array}{l}\text { A nation's 'brand' exists, with or without any conscious efforts in nation branding, as each country } \\
\text { has a current image to its international audience, be it strong or weak, clear or vague. }\end{array}$ & (Fan, 2006) \\
\hline Every nation is a brand and most nations have had their brands made for them. & $\begin{array}{c}\text { (Loo \& Davies, } \\
\text { 2006) }\end{array}$ \\
\hline $\begin{array}{l}\text { A nation brand reflects the complex reality of a country by encapsulating its culture, history, peoples, } \\
\text { government and business in a short motto or image. }\end{array}$ & (Anholt, 2007) \\
\hline $\begin{array}{l}\text { The key commercial objectives of nation branding are to boost export promotion, } \\
\text { inward investment and tourism. } \\
\text { One of the major tasks of nation branding is to counter the negative image of the nation in order for } \\
\text { the nation's economy and reputation to blossom. }\end{array}$ & (Dinnie, 2008) \\
\hline $\begin{array}{l}\text { Nation branding has emerged as a strategy for all countries to compete financially, culturally and } \\
\text { politically in the global economy. }\end{array}$ & (Augustine, 2009) \\
\hline $\begin{array}{l}\text { What nation branding concerns is the image and reputation a nation enjoys in the world. } \\
\text { Nation branding can be thought of as a nation's attempt to create and manage a brand for itself, } \\
\text { which serves to promote all the nation's offerings to its target market and thereby create a positive }\end{array}$ & (Hensen, 2010) \\
\hline
\end{tabular}




\begin{tabular}{|l|c|}
\hline image of the nation. & \\
\hline $\begin{array}{l}\text { A strong nation brand helps in differentiating a nation's output and gives it an advantage in } \\
\text { competing for financing, top talent and tourism. }\end{array}$ & (Haigh, 2012) \\
\hline $\begin{array}{l}\text { The impact of the nation brand on investment is that it encourages domestic investment through } \\
\text { encouraging local commerce to invest in the local market as opposed to investing abroad, while } \\
\text { externally attracting FDI as well as business relocation. }\end{array}$ & $\begin{array}{c}\text { (BrandFinance, } \\
\text { 2013) }\end{array}$ \\
\hline
\end{tabular}

Source: Author's own construction

Increased nation-based competition has seen nations increasingly employing marketing and branding techniques, to devise sources of competitive advantage. One of the key premises highlighted (Table 3 ) is that even if a nation does not make a conscious effort to brand itself or manage its reputation, the market will still have images and opinions of that nation formed by external entities, such as the international media. As a result, the simple association of a nation's name will reflect on products/services associated with that nation, greatly influencing investing, buying and travelling decisions. The crux of this paper is, whether African countries could utilise nation branding as a tool to change its current image, create a new and positive image, and manage it effectively, to compete regionally and globally for FDI. In essence make full utilisation of nation branding as an investment promotion tool, aimed at attracting FDI into their individual economies. Purushottam (2010) identifies country branding as an example of an image improvement approach, at a national level, citing African country positioning cases of Uganda - 'Africa's friendliest country'; Ethiopia - 'Thirteen months of sunshine'; Nigeria - 'Good people, great nation'; Egypt - 'Nothing compares to Egypt' under the campaign 'The gift of the sun'.

\section{Nation Branding Practise}

The use of branding techniques by African governments, to gain competitive advantage as investment destinations, over other nations is possible (Dinnie, 2008). It is important to note that, in practise nation/country branding is not just the creation of catchy slogans, logos or prominent association. As (Akoita, Sa) affirms, country branding, involves planned communication management, and purposeful social engineering. Similarly, the nation brand is not one dimensional as Belloso (2010) alludes to, by specifying that the nation brand is either:

i. An existing image or perception, that is, the country brand viewed as an image or reputation or,

ii. A unique value position, that is to say the country brand, viewed as a tool to raise people's interest in investing, visiting or doing business in a particular country.

In the case of African nations one may suggest that nation branding would be a combination of both dimensions that is.

i. Taking into account a nation's existing image, and the perceptions that exist of the nation, which inform investors, of the overall reputation the nation has, as an investment destination and then,

ii. Developing a unique value position, whereby the brand is then used as a tool to raise interest, within the investment community.

Brand Australia (2011) interprets nation brand as the representative of a country as a whole, highlighting that successful nation branding identifies the gaps that exist between a nation's reputation, and its capabilities in reality, and addresses those gaps. This holds true, given that a nation's reputation abroad has 'substantial' ramifications for the nation's ability to, excel in areas such as trade, investment attraction, tourism, and in its cultural and diplomatic relations with other nations (Brand Australia, 2011). Marketing and branding is no longer confined to the commercial field, with the application of branding techniques having made inroads into other fields, namely:

- Politics - for instance the African National Congress (ANC) and the Democratic Alliance (DA), marketing and branding themselves amongst voters as the political parties of choice during the 2011 local government elections;

- Government Policy - for instance South Africa marketing itself globally through the International Marketing Council (IMC), as a nation 'Alive with Possibility', through a government initiated international marketing program;

- Tourism Marketing - in the instances of Australia and New Zealand, which market themselves as the best natural tourist destinations in the world and;

- Education Promotion - as is the case with the University of Witwatersrand, branding itself as a world-class 
university, through its prominent alumni network, in adverts on South African television.

\section{Investment Promotion}

An investor can be described as an individual or corporate entity that has resources to finance and/or contribute to a business undertaking, both locally and internationally. More pertinently, (Wells and Wint, 2000:8) define FDI as, "The establishment or purchase by residents of one country, of a substantial ownership and management share - usually measured by a minimum equity stake of $10 \%$ of a business, in another country." National governments today view the attraction of investors an important element in economic development, more so in the case of Africa. Investment promotion is essentially the act of marketing a country or region in order to attract and retain both foreign and investors respectively by communicating to investors the positive attributes of a nation as an investment destination (Khadzhynov, 2010, East African Community Secretariat-EACS, 2008, Zhang, 2005, Wells \& Wint, 2000, Wint, 1992). In an academic study, Trnik (2007) found that there are two main approaches to investment promotion; i) the neoclassical approach which is premised on the view that investors automatically seek out investment opportunities as long as a nation secures a good investment climate; and the more widely accepted ii) interventionist approach which suggests that a suitable investment climate may not be sufficient due to existing market failure as a result of perception or information gaps. It is the latter approach to attracting FDI that has resulted in the practice of modern marketing-related activities referred to as investment promotion.

Modern investment promotion consists of three basic activities conducted by governments or investment promotion agencies (IPAs), namely, creating an attractive image of a country as an investment destination, information provision to potential and current investors and providing services to prospective investors (Matiza \& Oni, 2013, Trnik, 2007, Wells \& Wint, 2000). In a paper on the acceleration of FDI to Africa, Musila and Sigue (2006) conclude that these activities as part of investment opportunity promotion, is a generally growing field in the marketing of places. This growth in activities is primarily as a result of governments needing to; 1) focus on and attract quality FDI, 2) keep up with the dynamic nature of nation-based competition for a finite pool of global FDI resources, 3) increase the quantity of foreign investment indirectly, by for instance improving the nation's investment image, 4) increase the number of firms competing to invest in the nation, and 5) increase the quantity of foreign investment indirectly, by for instance improving the nation's investment image, (UN, 2003, Wells \& Wint, 2000).

\section{Investment Destination Images}

Although the images of nations are highly subjective and unique to individual countries, Hermann (2010) classifies nation images into six distinct categories; overly attractive image, positive image, mixed image, weak image, contradictory image (people hold opposite views about some features of the place), and negative image. Each category has particular strategic challenges and those relevant to this discussion are those relevant to African nations with are primarily weak, contradictory and negative images and these are illustrated in Table 4,

Table 4: Image Situations of Nations

\begin{tabular}{|c|l|}
\hline Image Situations & \multicolumn{1}{c|}{ Strategic Challenge } \\
\hline Weak image & $\begin{array}{l}\text { Image improvement depending on the reasons for weak image - e.g. "visibility-problem". Marketing } \\
\text { strategy with a clear message and leadership, turning attractive features into competitive advantage. }\end{array}$ \\
\hline Contradictory Image & $\begin{array}{l}\text { Accentuation of positive image while simultaneously trying to change the realities that give rise to negative } \\
\text { images. }\end{array}$ \\
\hline Negative image & $\begin{array}{l}\text { Working out of a long-term strategy for a more positive profile via concrete developments and } \\
\text { improvements on the problematic fields / allocation of budgets to development activities. }\end{array}$ \\
\hline
\end{tabular}

Source: Hermann (2010:60) Adapted from: Kotler, Haider and Rein (2002:35-36) and Kotler, Hamlin, Rein and Haider (2002:79)

Based on Table 4, this paper posits that since the majority of African nations are in the above mentioned categories, African nations need to work on a long-term strategies to develop positive images of their countries, based on concrete developments, and tangible improvements that counter the negative image or at the very least initiate strategies to accentuate the positive aspects of their country's image while changing the negative realities that create negative 
perceptions. This would see the development of a sustainable Investment Brands for individual countries which would then positively contribute to the continent's overall image as an investment destination.

\section{Nation Branding and Image-Building in Investment Promotion}

The primary aims of nation branding are that of attracting business tourists and leisure visitors, stimulating FDI and/or facilitating export marketing (Dinnie, 2008). Bellosso (2010) expands on these aims of nation branding to include; aiding in the recovery of a nation's international credibility and investor trust; stimulating international partnerships like attracting aid or FDI; helping eliminate misconceptions, wrong perceptions or stereotypes; helping change perceptions with a change in government, or after a conflict; and changing specific scenarios or problems of having a negative impact on a country's image and reputation against actual reality. With particular reference to promoting foreign investment, BrandFinance (2013) posits that the nation brand would encourage investment by both local and foreign investors.

The role of nation branding in investment promotion becomes clear when exploring the function of image-building in investment promotion. Image-building in investment promotion can be described as the first critical step in the investment promotion process. The image-building process seeks to create a positive perception of a country as an investment location, often by re-branding the image of the location globally to build a perception of an ideal business location and turning a country into a trustworthy and resonant brand among investors (Homma, 2013, Khadzhyrov, 2010, EACS, 2008, Trnik, 2007, Piontkivsk \& Segura, 2003). Image building is at the core of investment promotion, especially for nations regarded as small or new to FDI attraction, nations that have gone through significant political or economic reforms or nations that have received negative or limited international media coverage, (Trnik, 2007).

This holds true for most African nations whose first critical step in investment promotion is to augment their images as investment destinations and then effectively communicating this new identity to the investment community. As the Asia Policy Research Company (2003) suggests, emerging economies will find it necessary to undertake 'positive imagebuilding' activities prior to launching full-fledged investment promotion programs, to more often than not, dispel negative images associated with the country and convince investors of the attractiveness of the country. Traditional image-building activities practiced by governments, IPAs and private entities on behalf of governments include advertising, public relations events, international mass media campaigns, investor forums and events, digital media platform development and relationship management (Trnik, 2007, Asia Policy Research, 2003, Wells \& Wint, 2000). Unfortunately these activities are futile if they are undertaken for a nation with a negative brand image. Hence it has become critical that a nation manage its brand image before undertaking any promotion activities. It is at this point that nation branding contributes to investment promotion.

\section{The Contribution of Nation Branding to FDI Promotion}

The study by Wells and Wint (2000) concluded that in some cases investors may have an unfavourable image of a country, be it a true reflection of that country or not, impacting on the ultimate investment decision. To this effect they strongly recommended that nations seek to correct their unfavourable images, before attempting to generate investment, particularly because, a potential investor must have some subjective preference (interest) in an investment site, long before a decision is made to invest. Of what consequence then is an existing nation brand to FDI inflows?

Kalamova and Konrad (2009) conducted a study on the relationship between nation brands and FDI. The study included an interesting insight into the Nation Brand Hexagon, and how the individual elements that make up the nation/country brand influence investment promotion, and ultimately investment inflows. Kalamova and Konrad (2009) then made the following associations between the dimensions of the country brand and FDI;

\subsection{Tourism}

Assuming that the nation is particularly attractive to tourists, the nation may attract market-seeking investors looking to invest in hotel infrastructure, resorts or provide tourism related services, to exploit the nation's attractiveness to tourists. Similarly business tourism would also boost the image of a nation, as an investment destination.

\subsection{Exports}

In the event that a nation has a particularly strong country of origin (COO) image, that is a positive "Made in" association 
with regards to reliability, quality, status and other positive stereotypes, efficiency and market-seeking investors may prefer to locate and invest in production facilities in that nation, to exploit this nation's marketability.

\subsection{Governance}

Governance has probably the most influence on the final investment decision among potential investors. Political factors such as beaurocracy, property rights, and financial regulation are intrinsic to the perceptions of investors, that is the more foreign business friendly the nation is perceived to be, the more favourably it may be perceived by investors.

\subsection{Investment and Immigration}

A nation's socio-economic conditions have an influence on whether potential investors and migrants would be willing to relocate to a particular nation. Since investment projects often require the temporary or permanent relocation, of the investor or a management team to the investment destination, the image of the nation as a place to work and live, becomes influential on investment flow. This implies that places perceived to be less hospitable, de-motivate travel and may ultimately deter investment.

\subsection{People}

The stereotypes that exist about a nation's people (labour) in a potential investment destination, also have an influence on investment decisions. Factors such as skills levels, basic education/professional qualifications, abilities and motivation levels all have a bearing on the operations of investment projects. The pool of labour available in a potential investment site, can make or break investment projects.

\subsection{Culture}

The perceptions of a nation's culture, history and achievements may also impact investor behaviour. An outstanding reputation for creativeness, innovation or research excellence, may give a nation subjective preference, from creative industries or innovators with considerable research and development.

Regardless of which element of the NBH the nation is particularly strong in, Smallbone (2008) points out that in seeking to attract FDI and benefit from its inflows, policy makers must consider that there are a host of potential investment locations, with homogenous characteristics which undermines the bargaining power of competing investment destinations. This, he acknowledges, leads to the so-called 'race to the bottom' where countries outbid each other as least cost locations, thereby prejudicing themselves of the full potential benefits of FDI. "As with business strategy, competition between places based on non-price advantages is ultimately more sustainable than that based on price alone." (Smallbone, 2008). Interestingly, according to a 2007 survey by UNIDO, cited by a UNCTAD (2011) report, investors ranked incentive packages $13^{\text {th }}$ as a factor of investing decisions, behind factors such as quality of life (11 ${ }^{\text {th }}$ ), and the presence of key clients $\left(8^{\text {th }}\right)$, meaning that incentives offered by governments to potential investors have to a certain extent become less relevant in the global marketplace.

\section{An Example of Nation Branding as an Investment Promotion Tool}

The previous discussion of nation branding in terms of its definition, sought to establish nation branding as a relevant aspect of branding and marketing practice in the global context, and nation competitiveness. Nation Branding was investigated as a marketing strategy, targeting foreign investors, in a bid to create preference for African nations as investment destinations, within the international business community.

FDI attraction policy includes undertaking promotion activities, and France is a commonly cited case of business development oriented nation branding for FDI promotion. Favre, (2008) in Dinnie (2008:239-242), offers a practical illustration of how a nation's brand, in this case France, can be managed for investment promotion. France, through its Invest in France Agency (IFA) launched a three year, €35 million investment promotion campaign in 2004 under the slogan, 'The new France, Where the smart money goes.' The campaign aimed to raise the economic profile of France, to attract new business and increase FDI inflows, by positively influencing investor perceptions of France. In other words, France embarked on an image building investment promotion program. 
The investment promotion initiative was implemented as a multi-stakeholder Private-Public partnership that included France's international business development agency, UBI France, France's tourism office, and the Ministry of Foreign Affairs, amongst others. The initiative targeted key investor source countries for France; the United States of America, the United Kingdom, Germany, Japan and China, utilising the strategic marketing approaches of advertising, public relations, printed press and web media. Some of the activities included:

- Intensive print advertising campaigns - 51 Advertisements in 21 international economic publications in 2004, 77 advertisements in 19 publications in 2005, and 59 advertisements in 17 well known financial publications in 2006, covering the USA, the UK, Germany and Japan.

- Micro site launch www.investin france.org in 2004

- Survey to gauge campaign effectiveness amongst managers in the target countries in 2005.

- Billboard Advert campaign in 2005 at international airports in target countries.

- Internet banner adverts on leading economic websites in 2005.

As a result of the branding initiative, France achieved the following:

- A survey of company managers conducted during the program, $55 \%$ of respondents in the US, UK, Germany and Japan felt the campaign had, "clearly demonstrated France's strengths," and another $61 \%$ in the US, UK, and Japan responded that the program made them view France in a new light. (TNS Sofres, 2005).

- FDI projects in 2006 created 40000 new jobs in France, a 35\% increase from 2005 levels.

- UNCTAD ranked France third globally, in terms of FDI inflows, with one of its target audiences the United States, as the leading investor, with US\$171 Billion in corporate investments in 2006.

- In 2007 France was ranked fourth in the world, in a survey on the most popular countries in the world (BBC World Service Survey 2007, cited by Favre 2008, in Dinnie, 2008:242).

Although the current economic crises in Europe has impacted negatively on France, as it has many other nations in the Euro-zone, France is a viable illustration of nation branding, used to great financial benefit as a tool for investment promotion. The case of France encapsulates the view of this paper of nation branding, being a potential promotion tool for African nations, to brand themselves as attractive and profitable investment destinations in the near-future.

The literature review outlined the concept of nation branding, by building its definition in the context of traditional branding, defining it as a commercial practice, highlighting its potential benefits as well as contextualising nation branding thematically. The literature also outlined research in investment promotion, strategies, as well as best practices in investment promotion, before linking nation branding in practice and investment promotion.

\section{Emerging Issues and Conclusion}

This paper has examined the concepts of nation branding and investment promotion. The literature elucidated that image building cannot be implemented as a stand-alone investment generation approach, but is a critical initial stage of a proactive active investment promotion process. Most African nations will need to follow the three step approach to investment promotion. This is because the weak, negative or contradictory images inherent of African nations entail the need to re-engineer their images, and establish positive investment destination images within the investment community. African nations would need to implement proactive image-building activities before seeking to generate increased FDI. Based on the literature reviewed, this paper concludes that in the African context, and more specifically with nations such as Zimbabwe in mind, nation branding caters to the requirements of nations that need proactive and innovative approaches to overcoming the challenge of negative stereotyping and perception in order to effectively compete for FDI. Nation branding is in essence, the key catalyst for the initiation of investment promotion for African nations.

Probably the most important observation drawn from the review of literature, is that there is limited theoretical literature on nation branding as an investment promotion tool, meaning that, much like the concept of nation branding itself, the sub-fields of nation branding such as Investment Branding by nations, is still relatively new, and has room for theoretical development. In practice there are a lot of illustrations of nations actively using branding techniques to further their economic interests through FDI promotion. However, there is potential for more empirical research that could only serve to enrich the fields of both nation branding and investment promotion by establishing a theoretical framework that links nation branding theory with image-building practice in investment promotion. 


\section{References}

Adams, S. (2009). Can foreign direct investment (FDI) help promote growth in Africa? African Journal of Business Management, 3(5), pp178-183.

African Economic Outlook (2011). African Economic Outlook 2011. The African Development Bank (AfDB), Development centre for the Organisation for Economic Co-operation and Development (OECD) and United Nations Economic Commission for Africa. UN Publications.

Asia Policy Research Company. (2003). Image building and media relations (Module 3). United Nations ESCAP Training Workshop on Investment promotion and Facilitation.

Avraham, E \& Ketter, E. (2008). Media strategies for marketing places in crisis: Improving the image of cities, countries and tourist destinations. Oxford: Butterworth-Heinemann.

Bellosso, J.C. (2010). Country brand. A differentiation mechanism and source of intangibles. Paradigmes, Issue No 5 (October 2010), pp 44-51.

Blancheton, B \& Opera-Opimba. (2010). Foreign direct investment in Africa: What are the key factors of attraction aside from natural rsources? Working papers of Gretha, No 2010-14. [Online] Available: http://www.ideas.respec.org/p/grt/wpegrt/2010-2014.html. (December 18, 2013)

Blythe, J. (2009). Key concepts in marketing. UK: Sage Publications.

Brand Australia (2011). [Online] Available: http://brandaustralia.gov.au. (August 23, 2011).

BrandFinance (2013). Brand Finance Nation Brands. The annual report on nation brands. [Online] Available: http://www.brandfinace.com. (December 18, 2013).

Darley, W.K. (2012). Increasing Sub-Saharan Africa's share of foreign direct investment: public policy challenges, strategies and implications. Journal of African Business, 13(1), pp 62-69.

De Best, Maya. (2010). Who shapes the image of the Netherlands? An analysis of the stakeholders that influence the image of a country. Master's Thesis. Erasmus University, Rotterdam. Faculty of history and Art. August 1 2010. [Online] Available: http://oaithesis.eur.nl/ir/repub/asset/8061/Thesis_mdebest_final20100820.pdf. (April 13, 2011).

Dinnie, K. (2008). Nation Branding: Concepts, Issues, Practice. Oxford: Butterworth-Heinemann

Dinnie, K. (2009). Leveraging nation branding equity - potential strategies for Trinidad and Tobago. Contact, the magazine of the Trinidad and Tobago chamber of Commerce.

Dinnie, K. (2012). More than tourism: the challenge of nation branding in Asia. [Online] Available: http://www.globalasia.org. (January 15, 2013).

Duah, Agyeman, Rachel. P. (2010). Nation branding as a tool for the increase of foreign direct investment. Dissertation BSc Business Administration. Ashesi University College. Ghana.

East African Community Secretariat, (2008). Draft roadmap towards effective promotion of investment in EAC. East African Community Secretariat. Arusha, Tanzania.

Fan, Y. (2006), "Nation Branding: What is Being Branded?". Journal of Vacation Marketing, 12(1), pp 5-14.

Fan. Y. (2009). Branding The Nation: Towards a Better Understanding. Brunel University. [Online] Available: http://www.bura.brunel.ac.uk/.../NB\%20Towards\%20a\%20better\%20understanding.pdf. (March 6, 2010).

Grundey, Dianora, Tolub, B \& Brukiene, J. (2006). Country image as a marketing tool for fostering innovation and entrepreneurship. Kaumas Faculty of Humanities. Vilnius University. Lithuania

Gudjonsson, H. (2005). Nation branding. Journal of Place Branding, 1(3): pp 283-98.

Haigh, D. (2012). Foreword. Brand Finance Journal. Special Nation Brands Issue: August 2012. 2

Hawkins Penelope \& Lockwood, K. (2001). A strategy for attracting Foreign Direct Investment. Presented to the Economic society of South Africa, Bi-annual Conference. Glenburn Lodge (September 13, 2001).

Helmi Jessica \& Mulyanegara Riza Casidy. (2011). A conceptual framework on the relationship between nation brand perception and donation behavior. International Journal of Business and Management. 6(12), 36-42.

Hermann, Anna-Marie, B. (2010). Competitive identity management - symbolic capital promotion and accumulation by public policy based mental mapping (GM-S.C.P \& A): Nation branding and public diplomacy in Sweden. Doctoral Thesis. University of Wien.

Homma, T. (2013). Investment promotion - practical implications from JICA's experience in Zambia and others. Presentation at the $3^{\text {rd }}$ High level Forum for the Phase 2 of policy Dialogue of Industrial Development in Ethipoia. Addis Ababa, January 16, 2013.

Kalamova, Magarita. M \& Konrad, K.A. (2010). Nation Brands and Foreign Direct Investment Research Paper. Max-Planck-Institute for Intellectual Property Rights, Competition and Tax Law. Berlin: The Social Science Research Centre.

Kaneva Nadia. (2011). Nation Branding: Toward an Agenda for Critical Research. International Journal of Communications, 5(2011). pp117-141.

Kazembe, P \& Namizinga, N. (2007). The impact of foreign direct investment on development: Policy challenges for Malawi. The government of Malawi, ministry of industry, trade and private sector development. Integrated framework policy analysis working paper series No.6.

Khadzhynov, I. (2010). Investment promotion agencies are effective in attracting foreign direct investments. Donetsk National University, Ukrain.

Loo, Theresa \& Davies, G. (2006). Branding China: the ultimate challenge in reputation management? Corporate Reputation Review, 9(3), pp198-210. 
Marat, Erica. (2009). Nation branding in Central Asia: A new campaign to present ideas about the state and the nation. Journal of Europe_Asia Studies, 61(7), pp1123-1136.

Markiessinis, A. (2010). A pocket dictionary of Nation Branding. [Online] Available: http://www.nationbranding.info. (June 26, 2010).

Matiza, T \& Oni, O.A (2013). Nation branding as a strategic marketing approach to foreign direct investment promotion: The case of Zimbabwe. Mediterranean Journal of Social Sciences. Rome: MCSER Publishing, 4(13), pp 475-488.

Morgan, N, Pritchard, A, \& Pride, R. (2002). Destination branding - creating the unique destination proposition. Butterwoth-Hienemann.

Moyo, Dambisa (2010). Branding Africa: Taking ownership and responsibility. Brand Africa Forum Report 2010. [Online] Available: http://www.brandafrica.net ((January 2, 2014).

Murai, Y. (2011). 'Alive with Possibility'. Brand South Africa and the discursive construction of South African identity. Media @ LSE Economics. MSc Dissertation, London School of Economics.

Musila, J.W. \& Sigue, S.P. (2006). Accelerating FDI to Africa from policy statement to successful strategies. Journal of Managerial Finance, 32(7)

Mwilima, N. (2003). Foreign direct investment in Africa. Africa labour research network social observatory pilot project - Final draft report. Labour Resources and Research Institute.

Odenthal, I \& Zimny, Z. (1999). Foreign direct investment in Africa: Performance and potential. United Nations Conference on Trade and Development (UNCTAD). UNCTAD/ITE/IIT/MISC.15.

Odle, M \& Gara, J. (1997). Survey of best practices in investment promotion. The United Nations Conference on Trade and Development (UNCTAD). [Online] Available: www.unctad.org/asit (June 8, 2011)

Organisation for Economic Co-operation and Development (OECD). (2010). Policy framework for investment toolkit. Investment promotion and facilitation. The Investment Division of the OECD Directorate of Financial and Enterprises Affairs (laRRI).

Otty, M \& Sita, A. (2011). Its time for Africa. Ernst \& Young 2011 Africa attractiveness survey. Oxford Economics.

Partzalis, J, \& Roderiguez, C.A. (2002), Country names and brands: Symbolic meaning and capital flows. [Online] Available: http://www.sba.muohio.edu/abas/1999/pantzajo.pdf. (March 13, 2010),

Piontkivska Iryna \& Segura, E.L. (2003). Survey of international foreign investment promotion practices. (12). The Bleyzer Foundation.

Purushottam, Neha. (2010). Country branding: South Africa potential of 'Ubuntu' in branding South Africa. CEO, 9(2), 2010.

Sichei, M.M \& Kinyondo, G. (2012). Detrerminants of FDI in Africa: A panel data analysis. Global Journal of Management and Business Research, 12(18), pp 84-97.

Smallbone, D. (2008). Foreign direct investment and SME development: Some policy issues for transition and developing countries. Small Business Research Centre, Kingston University.

Szondi, G. (2008). Public diplomacy in nation branding: Conceptual similarities and differences. [Online] Available: http://www.clingendael.nl/publications/2008/20081022_pap_in_dip_nation_branding.pdf. (March 13, 2010)

Teslik, L.H. (2007). Nation branding explained. [Online] Availab̄le: http://cfr.org/information-and-communication/nation-brandingexplained/p14776. (July 3, 2012).

Trnik, M. (2007). The role of investment promotion agencies at attracting foreign direct investment and their impact on economic development in Central Europe. (The Czech Republic and Slovakia in comparative perspective). Master of Arts Dissertation, international relations and European Studies, Central European University, Budapest, Hungary.

United Nations (1995). Reviving investment in Africa: Constraints and policies. Economic Commission for Africa: Ethiopia.

United Nations ESCAP (2003). Investment promotion techniques: Module 5. Training workshop on Investment Promotion and Evaluation.

United Nations Conference on Trade and Development (2011). Foreign direct investment in LDC's: lessons from the decade 2001-2010 and the way forward. United Nations Conference on Trade and Development. [Online] Available: http://www.unctad.org/wir. (July 3, 2012).

United Nations Industrial Development Organisation . (2011). Africa Investor Report 2011-Towards evidence-based investment promotion strategies. United Nations Industrial Development Organisation. ISBN: 978-92-1-1-106450-6.

Venter, P \& van Rensburg, Mari-Jansen. (2009). Strategic marketing: Theory and applications for competitive advantage. Cape Town: Oxford University Press.

Vicente, J. (2004). State branding in the 21st century. Master's Thesis in Law and Diplomacy. The Fletecher School.

Wells, L, T \& Wint, A, G. (2000). Marketing a country: Promotion as a tool for attracting foreign investment. Revised Edition (March 2000). Foreign Investment Advisory Service. Occasional Paper $13 . \quad$ [Online] Available: http://www.rru.worldbank.org/Documents/PapersLinks/244.pdf . (May 8, 2010).

Zhang, J. (2005). Targeted direct investment promotion strategy: Attracting the 'Right' foreign direct investment for development. [Online] Available: http://www.policyinnovations.org/ideas/policy_library/data/01179/-res/id=safild/ (January 1, 2014). 